http://kitaibelia.unideb.hu/

ISSN 2064-4507 (Online) • ISSN 1219-9672 (Print)

(C) 2015, Department of Botany, University of Debrecen, Hungary

20 (2): 206-212.; 2015

DOI: $10.17542 /$ kit.20.206

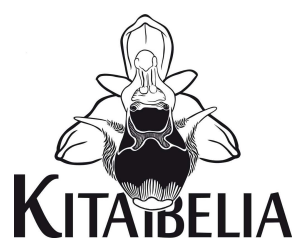

\title{
Mohaflorisztikai vizsgálatok az egykori almásfüzitői timföldgyár környékén
}

\author{
SzǗcs Péter \\ Eszterházy Károly Főiskola TTK Biológiai Intézet, Növénytani és Ökológiai Tanszék, H-3300 Eger, Leányka utca 6.; \\ szucs.peter@ektf.hu

\section{Bryofloristial studies in an abandoned alumina refinery near Almásfüzitő, NW Hungary (a case study)}

\begin{abstract}
Based on data collected during field surveys between 2012-2014, the author presents the results of bryofloristical studies carried out in an abandoned alumina refinery. The author has detected altogether 46 bryophytes from the territory, of which 15 species are new to the bryoflora of the settlement. In the surroundings of the industrial zone (where alumina production was carried out until 1997) some bryophytes, which are classified as least concern (Brachythecium albicans, Brachythecium tommasinii, Rhynchostegium murale) and near threatened status in the Hungarian Red List (Aloina aloides, Brachythecium glareosum, Dicranella staphylina, Didymodon insulanus, Orthotrichum pumilum), can be found.
\end{abstract}

Keywords: bryoflora, industrial zone, near-threatened mosses, special substrates

Összefoglalás - A 2012-2014 közötti időszakban végzett mohaflorsztikai kutatások eredményeképpen összesen 46 mohafaj azonosítása történt meg az almásfüzitői timföldgyár környékéről, melyek közül 15 taxon új Almásfüzitőre. Az ezredforduló előtti évtizedekben intenzív termelést folytató, mára felhagyott ipari gyáregység és a hozzá kapcsolódó területek különféle mesterséges élőhelyein a közönséges fajok mellett természetvédelmi szempontból figyelmet érdemlő (Brachythecium albicans, Brachythecium tommasinii, Rhyncostegium murale) és veszélyeztetettség közeli (Aloina aloides, Brachythecium glareosum, Dicranella staphylina, Didymodon insulatus, Orthotrichum pumilum) mohataxonok is megtalálják életfeltételeiket.

Kulcsszavak: ipari övezet, mohaflóra, speciális aljzatok, veszélyeztettség közeli fajok

\section{Bevezetés}

A hazai mohaflorisztikai témájú kutatásokkal és publikációkkal összefüggésben általánosságban kijelenthető, hogy döntően természetvédelmi szempontból értékes, természetközeli élőhelyek feltárása összpontosítanak. Ebből adódóan a magyarországi lakott területek, antropogén élőhelyek és ipari övezetek mohaflórája kevésbé ismert vagy teljességgel ismeretlen a tudomány számára.

Almásfüzitő ebben a tekintetben kivételnek számít, mohaflórája viszonylag jól feltárt. A korábbi vizsgálatok döntően a nagykolóniai lakótelep művi létesítményeire, zöldfelületeire, duna-parti élőhelyekre és a községhez tartozó kavicsbánya területére koncentráltak (SzŰCS \& LóTH 2008).

Jelen közlemény az almásfüzitői timföldgyár területének és közvetlen szomszédságában fekvő másodlagos élőhelyeknek a mohaflóráját mutatja be. 


\section{Anyag és módszer}

A terepi gyűjtések 2012 és 2014 között zajlottak (1. ábra). A májmohák nomenklatúrája GRolle \& LONG (2000), a lombosmoháké HiLl et al. (2006) munkáját követi. A bizonyító példányokat az Eszterházy Károly Főiskola Növénytani és Ökológiai Tanszékének kriptogám herbáriumában (EGR) valamint a Botanischer Garten und Botanisches Museum BerlinDahlem (B) moha kollekciójában helyeztük el.

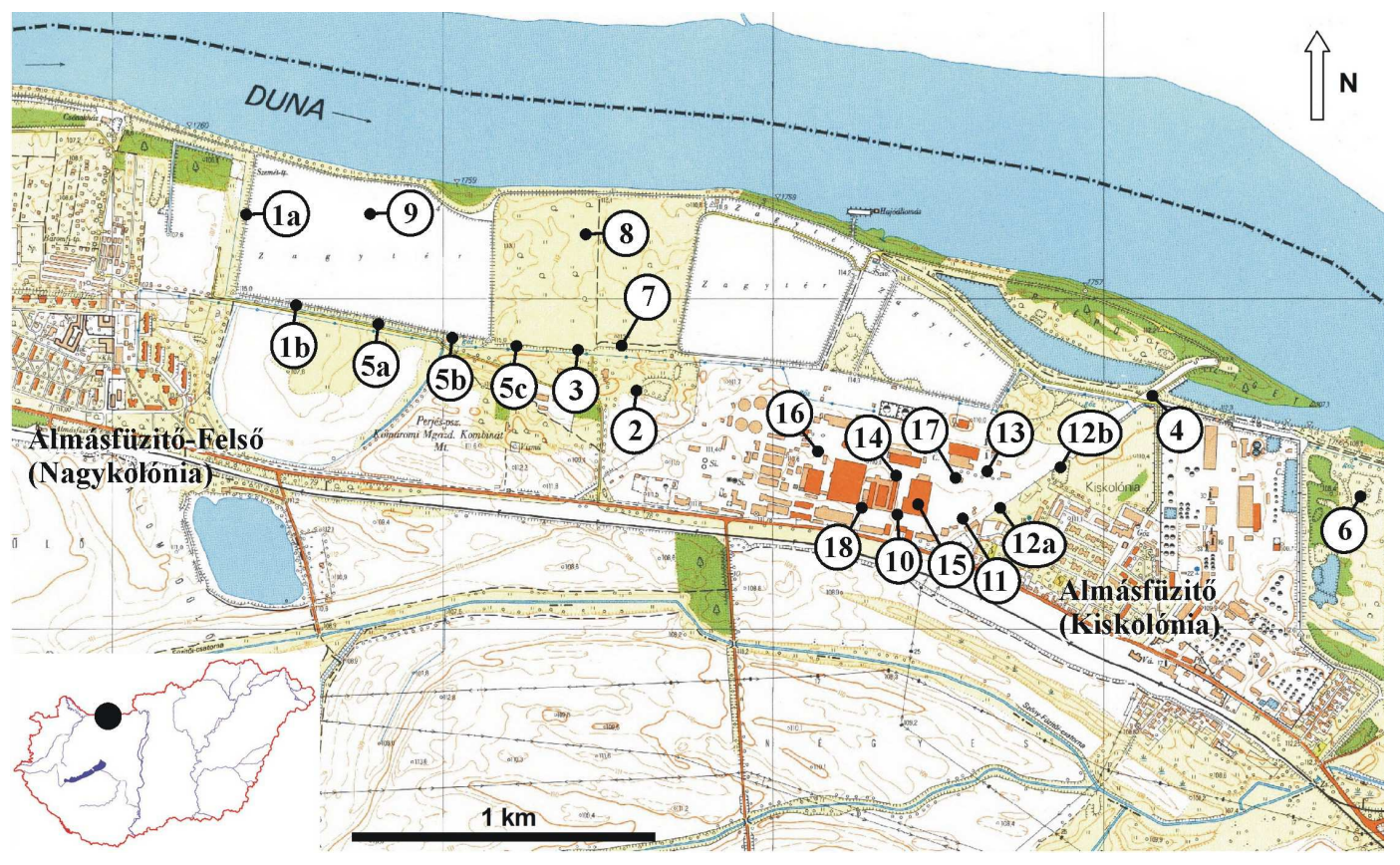

1. ábra. A kutatási terület a számokkal jelzett gyűjtési pontokkal.

Fig. 1. Map of the studied area with sampling sites.

\section{A kutatási terület ismertetése}

A több mint 3000 lélekfős Almásfüzitő $\left(8,2 \mathrm{~km}^{2}\right)$ a Komárom-Esztergomi síkságon terül el, 100-120 méter tengerszintfeletti magasságban. A kistájat enyhén bázikus neogén homokos üledék, valamint folyami és deflációs eredetű homoktalajok fedik. A klíma mérsékelten meleg és mérsékelten száraz, az évi középhőmérséklet 9,8 és $10,2^{\circ} \mathrm{C}$ közötti, az éves csapadékmennyiség pedig 550 és $580 \mathrm{~mm}$ között alakul. Legfontosabb vízfolyása a Duna, melynek holtágából két tavat is kialakítottak (Prépost- és Olajos-tó), ezenkívül a település két kavicsbánya tóval is rendelkezik (DövÉNYI 2010).

Az almásfüzitői timföldgyár 1950 novemberében kezdte meg tevékenységét, mellyel közel egy időben épült meg a nagykolóniai lakótelep. A gyár működése során a technológiai folyamat részeként keletkezett vörösiszapot a gyár szomszédságában kialakított zagykazettákban helyezték el. A zagyterek által elfoglalt nettó összterület közel 167 ha. A timföldgyár 1997-es bezárásáig összesen 16 millió tonna vörösiszap deponálása történt meg. A vörösiszap-tározó kazetták többségét az elmúlt 20 év folyamán rekultiválták, felszínüket ma már spontán vegetáció borítja (E. NAGY 2014). 
Gyúitési helyszínek

Komárom-Esztergom megye, Almásfüzitő:

1. rekutivált vörösiszap-tározó mellett, felhagyott kavics szerviz út mellett (2012. 12. 29.,

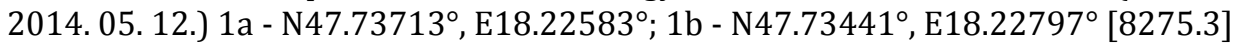

2. rekutivált vörösiszap tározók mellett, bolygatott ruderális élóhely és vegetáció, kis tisztásnál (2014. 05. 12.) N47.73308, E18.24252 [8275.3]

3. rekutivált vörösiszap tározók mellett, idős beton építmény és ruderális élőhely (2014. 05. 12.) $\mathrm{N} 47.73352^{\circ}, \mathrm{E} 18.23908^{\circ}[8275.3]$

4. Prépost-tó mellett futó iparvágányok között (2014. 05. 12.) N47.73252 E18.26272 [8275.4]

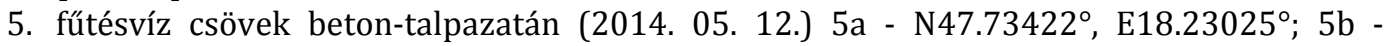
$\mathrm{N} 47.73363^{\circ}, \mathrm{E} 18.23580^{\circ} ; 5 \mathrm{C}-\mathrm{N} 47.73358^{\circ}, \mathrm{E} 18.23763^{\circ}$ [8275.3]

6. rekutivált vörösiszap tározók mellett, spontán, másodlagos ruderális vegetáció (2014. 05. 12.) $\mathrm{N} 47.72988^{\circ}, \mathrm{E} 18.27141^{\circ}[8275.4]$

7. 4. számú rekultivált vörösiszap-tározó kazetta (2014. 06. 13.) N47.73391, E18.24094 [8275.3]

8. 5. számú rekultivált vörösiszap-tározó kazetta (2014. 06. 13.) N47.73627², E18.23988 [8275.3]

9. 6. számú rekultivált vörösiszap-tározó kazetta (2014. 06. 13.) N47.73766 E18.22936º [8275.3]

10.timföldgyár bejárata közelében, vasúti síneknél (2014. 06. 13.) N47.72891, E18.25275 [8275.4]

11. bauxit tároló körcsarnokban (2014. 06. 13.) N47.72947, E18.25480 [8275.4]

12. Timföldgyár, ipari vágányok között (2014. 06. 13.) 12a - N47.73022, $\mathrm{E} 18.25800^{\circ} ; 12 \mathrm{~b}$ $\mathrm{N} 47.73122^{\circ}, \mathrm{E} 18.25947^{\circ}[8275.4]$

13. Timföldgyár, vasúti szerelőcsarnok mellett (2014. 06. 13.) N47.73080, E18.25705 [8275.4]

14. Timföldgyár, ülepítő közelében (2014. 06.13.) N47.73027ㅇ, E18.25286² [8275.4]

15.Timföldgyár, épület mellett, gyepben $\left(2014.06\right.$. 13.) N47.73011º $\mathrm{E} 18.25369^{\circ}$ [8275.4]

16. Timföldgyár, kalcináló épület mellett (2014. 06. 13.) N47.73069º $\mathrm{E} 18.24958^{\circ}$ [8275.3]

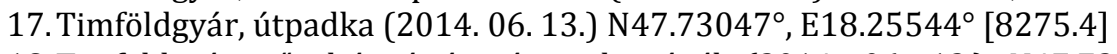

18.Timföldgyár, tűzoltó víztározó medencénél (2014. 06. 13.) N47.72911, E18.25133 [8275.4]

\section{Eredmények}

Az almásfüzitői timföldgyár területéről és környékérôl összesen 46 mohataxon került azonosításra, melyek közül 1 májmoha, 45 pedig lombosmoha. A kimutatott mohafajok döntő többsége országos viszonylatban közönséges és gyakori, nem veszélyeztetett (LC) vörös listás besorolású (PAPP et al. 2010). Ezek mellett ugyanakkor néhány figyelmet érdemlő (LC-att) (Brachythecium albicans, B. tommasinii, Rhynchostegium murale) és veszélyeztetettség közeli (NT) (Aloina aloides, Brachythecium glareosum, Dicranella staphylina, Didymodon insulanus, Orthotrichum pumilum) besorolású moha is fellelhető a kutatási területen.

Említésre méltó az élőhely indikátorok jelenléte; a Brachythecium tommasinii árnyas mészkősziklák jellemző faja, az Orthotrichum pumilum pedig fakéreg lakó.

A gyűjtések száma alapján elvégzett, egymáshoz viszonyított gyakorisági értékek alapján (2. ábra) a Ceratodon purpureus a leggyakoribb mohafaj a kutatási területen. Ezt követi csökkenő sorrendben a Brachythecium rutabulum, a Bryum caespiticium, a Barbula unguiculata és a Grimmia pulvinata. 


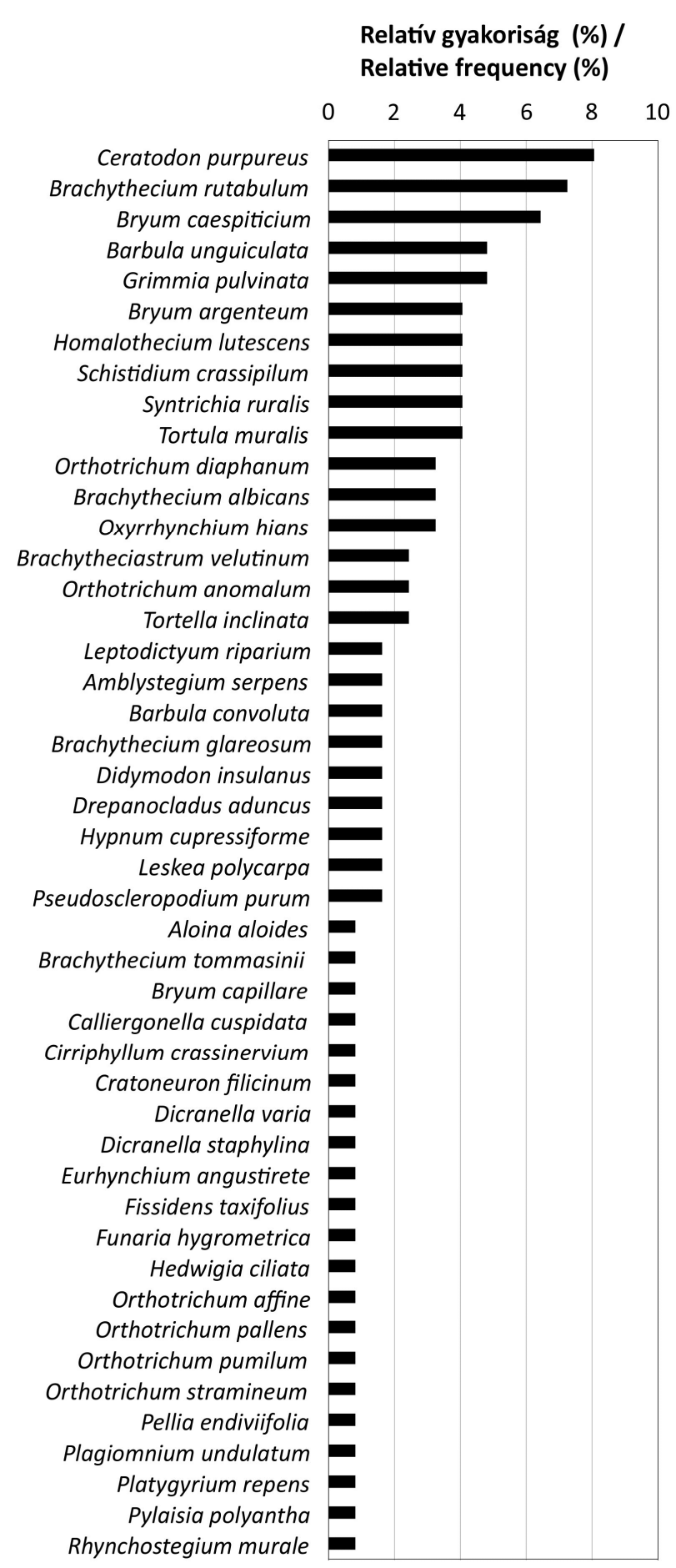

A legkisebb gyakorisági értékkel rendelkeznek a területre nézve ritka mohafajok, melyek a következőek: Aloina aloides, Brachythecium tommasinii, Bryum capillare, Calliergonella cuspidata, Cirriphyllum crassinervium, Ceratodon purpureus, Dicranella varia, D. staphylina, Eurhynchium angustirete, Fissidens taxifolius, Funaria hygrometrica, Hedwigia ciliata, Leptodictyum riparium, Orthotrichum pallens, Pellia endiviifolia, Plagiomnium undulatum, Platygyrium repens, Pylaisia polyantha, Rhynchostegium murale.

SzÛ́CS \& LóTH (2008) munkájához képest a következő mohák újak Almásfüzitő közigazgatási területére: Aloina aloides, Barbula convoluta, Brachythecium tommasinii, Calliergonella cuspidata, Dicranella staphylina, Drepanocladus aduncus, Eurhynchium angustirete, Fissidens taxifolius, Hedwigia ciliata, Orthotrichum affine, O. pallens, O. stramineum, Plagiomnium undulatum, Platygyrium repens, Schistidium crassipilum.

Aljzati kötődés tekintetében a mohamintáknak 41\%-a talajfelszínről, 36\%-a beton, műkő és kő aljzatról, 15\%-a fakéregről, 2,5\%-a gumiról, $\quad 3 \%$-a üveggyapotról, további 2,5\% pedig fém felületről származik (3. ábra).

2. ábra. Az észlelt mohafajok egymáshoz viszonyított relatív gyakorisága.

Fig. 2. Relative frequency of bryophyte species in the studied area. 


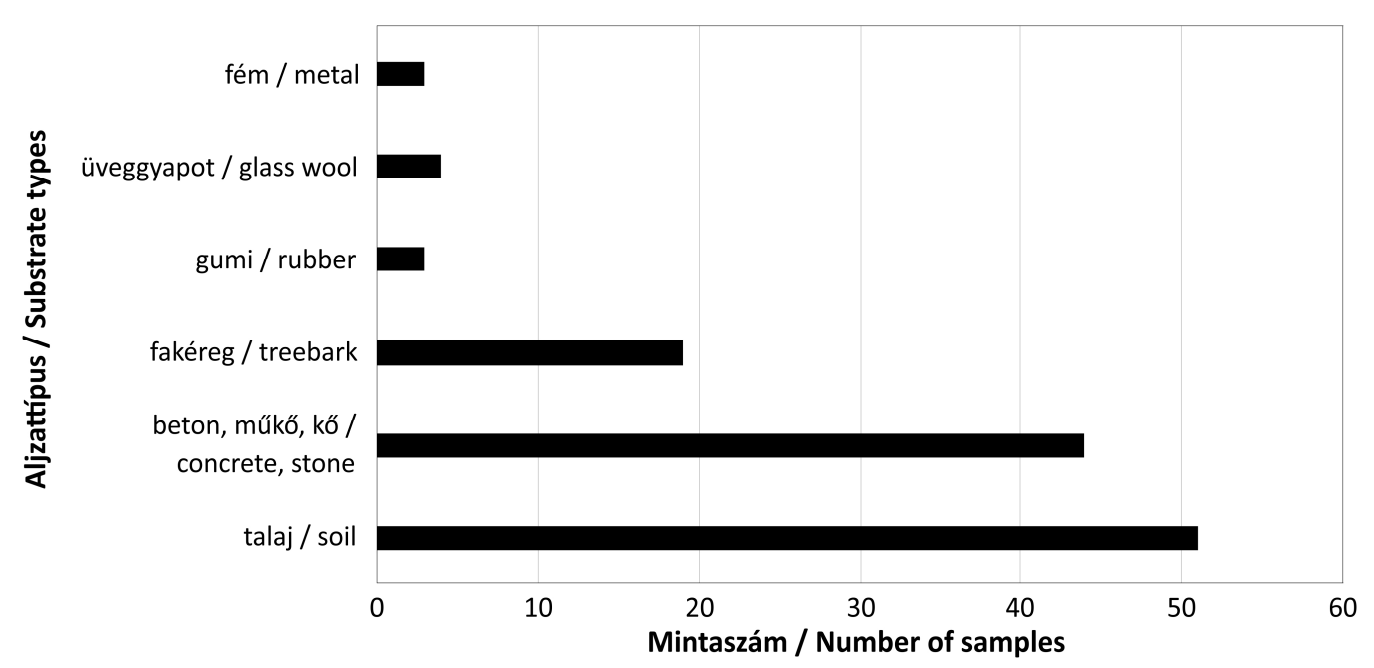

3. ábra. A talált mohafajok aljzat preferenciájának megoszlása.

Fig. 3. Spectrum of substrate preference of the registered bryophytes.

Enumeráció

Hepaticeae

Pellia endiviifolia (Dicks.) Dumort. - LC - 15: homoktalajon

Musci

Aloina aloides (Schultz) Kindb. - NT - 5: kaviccsal kevert talajon

Amblystegium serpens (Hedw.) Schimp. - LC - 7: talajon; 13: Populus tremula kérgén

Barbula convoluta Hedw. - LC - 7: talajon; 12: fém felületén

Barbula unguiculata Hedw. - LC - 4, 7, 8, 10, 12, 16: talajon

Brachytheciastrum velutinum (Hedw.) Ignatov \& Huttunen - LC - 7, 8: talajon; 13: Populus tremula kérgén

Brachythecium albicans (Hedw.) Schimp. - LC-att - 9, 10, 12: talajon, 17: műkövön

Brachythecium glareosum (Bruch ex Spruce) Schimp. - NT - 2: betonon; 17: műkövön

Brachythecium rutabulum (Hedw.) Schimp. - LC - 2, 7, 8, 9, 10, 12: talajon; 11: üveggyapoton; 11: betonon; 17: műkövön

Brachythecium tommasinii (Sendtn. ex Boulay) Ignatov \& Huttunen - LC-att - 4: betonon

Bryum argenteum Hedw. - LC - 7: talajon; 11: gumi felületen; 11, 18: betonon, 11:

üveggyapoton

Bryum caespiticium Hedw. - LC - 2, 7, 8, 9, 10: talajon; 12: fémcsavaron, 11: üveggyapoton;

18: betonon

Bryum capillare Hedw. - LC - 5: betonon

Calliergonella cuspidata (Hedw.) Loeske - LC - 2: talajon

Ceratodon purpureus (Hedw.) Brid. - LC - 4, 11: betonon; 10: Populus nigra kérgén; 11: gumi

felületen; 11: üveggyapoton; 12: fémcsavar felületén; 7,9,12, 14: talajon; 17: műkövön

Cirriphyllum crassinervium (Taylor) Loeske \& M.Fleisch. - LC - 10: talajon

Cratoneuron filicinum (Hedw.) Spruce - LC - 5: betonon

Dicranella varia (Hedw.) Schimp. - LC - 15: talajon

Dicranella staphylina H.Whitehouse - NT - 2: talajon

Didymodon insulanus (De Not.) M.O.Hill - NT - 12, 15: talajon

Drepanocladus aduncus (Hedw.) Warnst. - LC - 1, 6: talajon 
Eurhynchium angustirete (Broth.) T.J.Kop. - LC - 2: talajon

Fissidens taxifolius Hedw. - LC - 2: talajon

Funaria hygrometrica Hedw. - LC - 7: talajon

Grimmia pulvinata (Hedw.) Sm. - LC - 4, 5, 11, 12, 16, 18: betonon

Hedwigia ciliata (Hedw.) P.Beauv. - LC - 6: Robinia pseudoacacia kérgén

Homalothecium lutescens (Hedw.) H.Rob. - LC - 5, 11, 16: betonon; 11: gumi felületen; 17: műkövön

Hypnum cupressiforme Hedw. - LC - 4: betonon; 13: Populus tremula kérgén

Leskea polycarpa Hedw. - LC - 7: Populus nigra kérgén; 13: Populus tremula kérgén

Leptodictyum riparium (Hedw.) Warnst. - LC - 14, 15: talajon

Orthotrichum affine Schrad. ex Brid. - LC - 5: Sambucus nigra kérgén

Orthotrichum anomalum Hedw. - LC - 4, 12, 18: betonon

Orthotrichum diaphanum Schrad. ex Brid. - LC - 5: Sambucus nigra kérgén; 7, 10: Populus

nigra kérgén; 13: Populus tremula kérgén

Orthotrichum pallens Bruch ex Brid. - LC - 13: Populus tremula kérgén

Orthotrichum pumilum Sw. ex anon. - NT - 2: betonon

Orthotrichum stramineum Hornsch. ex Brid. - LC - 5: Sambucus nigra kérgén

Oxyrrhynchium hians (Hedw.) Loeske - LC - 2, 8, 14, 15: talajon

Plagiomnium undulatum (Hedw.) T.J.Kop. - LC - 2: talajon

Platygyrium repens (Brid.) Schimp. - LC - 7: Populus nigra kérgén

Pseudoscleropodium purum (Hedw.) M.Fleisch. - LC - 2, 10: talajon

Pylaisia polyantha (Hedw.) Schimp. - LC - 13: Populus tremula kérgén

Rhynchostegium murale (Hedw.) Schimp. - LC-att - 16: betonon

Schistidium crassipilum H.H.Blom - LC - 2, 4, 5, 11, 16: betonon

Syntrichia ruralis (Hedw.) F.Weber \& D.Mohr - LC - 4, 5, 9, 12, 18: betonon

Tortella inclinata (R.Hedw.) Limpr. - LC - 10, 14, 16: talajon

Tortula muralis Hedw. - LC - 5, 11, 16, 18: betonon; 7: kő felszínén

\section{Köszönetnyilvánítás}

Köszönettel tartozom Karánsebesy Lukács polgármesternek a kutatás támogatásáért, Pirik Sándornak (Almásfüzitői Iparfejlesztő és Hasznosító Kft.) és Tóth Lajosnak (Tatai Környezetvédelmi Zrt.) a terepi gyűjtések biztosításáért, valamint a kézirat lektorainak alapos munkájukért és javaslataikért. A közlemény a Társadalmi Megújulás Operatív Program Kutatás, Innováció, Együttmúködések - Társadalmi innováció és kutatási hálózatok együttmüködésének erősítése az Eszterházy Károly Főiskola, a Bay Zoltán Alkalmazott Kutatási Nonprofit Kft. és az Agria TISZK Közhasznú Nonprofit Kft. együttmúködésével címet viselő, TÁMOP-4.2.1.D-15/1/KONV-2015-0013 azonosító számú projekt keretében készült. A projekt az Európai Unió támogatásával és az Európai Szociális Alap társfinanszírozásával valósult meg.

\section{Irodalom}

DöVÉNYI Z. (szerk.) (2010): Magyarország kistájainak katasztere (Hungarian microregions). - MTA Földrajztudományi Kutatóintézet, Budapest, 876 pp.

E. NAGY L. (szerk.) (2014): Ember, természet, gazdaság, környezet (Komárom-Esztergom megyében). Gesher Kft., Budapest, 188 pp.

Grolle R. \& Long D. G. (2000): An annotated check-list of the Hepaticae and Anthocerotae of Europe and Macaronesia. - Journal of Bryology 22: 103-140.

Hill M. O., Bell N., Bruggeman-Nannaenga M. A., Brugues M., Cano M. J., Enroth J., Flatberg K. I., Frahm J. P., Gallego M. T., Gariletti R., Guerra J., Hedenäs L., Holyoak D. T., Hyvönen J., Ignatov M. S., Lara F., 
MAZIMPAKA V., MUNOZ J. \& SÖDERSTRÖM L. (2006): An annotated checklist of the mosses of Europe and Macaronesia. - Journal of Bryology 28: 198-267.

PApp B., ERZBerger P., Ódor P., Hock Zs., Szövényi P., Szurdoki E. \& Tóth Z. (2010): Updated checklist and Red List of Hungarian Bryophytes. - Studia botanica hungarica 41: 31-59.

Szû́cs P. \& LóTH H. (2008): Almásfüzitő antropogén élőhelyeinek mohaflórája. - Komárom-Eszergom Megyei Múzeumok Közleményei 13-14: 399-423.

Beérkezett / received: 2015. 09. 22. • Elfogadva / accepted: 2015. 10. 02. 